\title{
ТВОРЧИЙ ПОРТРЕТ ЯК СПОСІБ ПІЗНАННЯ ОСОБИСТОСТІ МИТЦЯ
}

\author{
Асталош Г. Л., Микуланинець Л. М.
}

\section{ВСТУП}

Функціонування культури постмодернізму дедалі більше характеризується антропологічною кризою. Для неї визначальним є: нівелювання гуманізму в житті homo sapiens (М. Хоркмаєр), підміна особистісних цінностей загальними ідеями (Т. Адорно), втрата суб'єктом свого обличчя (М. Фуко). Разом із тим проблема персони та пошуки іiі власного “Я”, взаємодія індивідуального й загальнолюдського стали предметом аналізу багатьох мислителів (Ж. Бодріяр, Р. Барт, Д. Дерріда, Ж.Ф. Ліотар, М. Фуко, М. Хайдеггер та ін). Особливої актуальності на межі XX-XXI століть набувають розвідки, що розглядають творчий портрет певного митця, його здобутки в матеріальній і духовній сферах. Вони експлікуються науковцями як виразники домінуючих соціокультурних, політичних, історичних та ін. ознак тієї доби, в яку функціонувала креативна персона. На нашу думку, вивчення iї онтологічного досвіду, втіленого у власних надбаннях, сприятиме вирішенню гуманістичних проблем сучасної цивілізації.

Наукова новизна розвідки полягає в тому, що вперше в національному мистецтвознавстві подано визначення терміна «творчий портрет», виявлено його особливості, аргументовано думку, що зазначений феномен $\epsilon$ засобом усвідомлення духовного світу майстра.

Можемо констатувати, що нині існує значна кількість досліджень, присвячених портрету (як методу відбиття зовнішніх і внутрішньопсихологічних рис особистості) та його побутуванню в різних формах художньої діяльності. Фундаментальні праці 3 цієї квестії, що експлікують смисл зазначеного жанру, представлені в письменстві, живописі, кінематографі, музиці (М. Андроннікова, В. Барахова, I. Неверова, Юньцзе Лі та ін.). Вчені опановують його як елемент літературного тексту (Л. Воронова, Б. Галанов, М. Мельник), естетичну категорію (Є. Басін, А. Габричевський), спосіб тлумачення сенсу людини (О. Коновалова, Г. Нечитайло) тощо. Однак, незважаючи на немалий об'єм робіт, майже зовсім не осягнутим залишається сутність дефініції «творчий портрет» (хоча вона вже щільно увійшла в 
національну мистецтвознавчу думку), а також роль цього виду пізнання в інтерпретації індивідуальності креативної персони.

Mema cmammi - на основі аналізу та узагальнення праць із філології, мистецтвознавства та культурології сформулювати зміст поняття «творчий портрет», висвітлити його специфіку та основні критерії написання, виявити значення у пізнанні особистості митця.

\section{1. Портрет як феномен культури}

Портрет в європейському мистецтві виник у живописі та скульптурі. Його характерною особливістю є точна передача зовнішніх рис натури, розкриття їі ментальних закономірностей через графічне зображення. Центром жанру є людина, прагнення майстра через документальність втілити ії правдивий образ. Портрет пройшов значний шлях розвитку та видозмінення, поступово заявив про себе в музиці (XVII-XVIII ст.), літературі (XIX ст.), кінематографі (XX ст.) та інших галузях творчості. Він отримав наукову інтерпретацію у працях мислителів.

Термін «портрет» активно використовується в психології (психологічний портрет), соціології (соціологічний портрет), лінгвістиці (мовний портрет), мистецтвознавстві (творчий портрет) та ін. У сучасних культурологічних джерелах він тлумачиться як: спосіб естетичного пізнання індивіда (А. Алпатов, М. Андроннікова, Л. Казанцева та ін.); вищий різновид художньої практики (М. Андроннікова, Л. Зінгер, А. Сидоров та ін.); цілісний опис суб’єкта, що виражає провідні ознаки внутрішнього світу (М. Андроннікова, Л. Зінгер, В. Віппер та ін.). Представлені погляди виводять розуміння жанру на рівень певної форми людинознавства. У ній одержують втілення соціальні, естетичні, етичні, філософські уявлення про особистість.

Роль портрета в житті європейської цивілізації є значущою. Він органічно включений у всю систему культури. Ця форма творчості тісно пов'язана 3 поняттями «імідж», «харизма», «образ», які відображають важливість презентації індивіда, його власного «Я». Через зазначений жанр мистецтво відтворює зовнішній вигляд i внутрішній стан конкретно існуючої персони, здійснює ретрансляцію того реального, що існувало в минулому або є в сьогоденні людства.

Багато дослідників намагалися сформулювати найбільш адекватне визначення змісту портрета у різних видах художньої діяльності, яке б дало ключ до розуміння цивілізаційної ролі. Сам термін походить від старофранцузького «рortraire» та позначає змалювання оригіналу «риса до риси», «риса за рису». Його витоки беруть початок від латинського дієслова «protrahere», що тлумачиться як «витягати на поверхню», «знаходити», пізніше воно отримало експлікацію - «зображати». 
Портрет у певні історичні періоди був не тільки жанром, який змальовував образ індивідуума, але і виражав найтиповіші ознаки епохи, втілював світоглядні орієнтири. По своїй суті, він ілюстрував основні квестії, які вперше постали перед людством у працях філософів. Тому цілком закономірно, що в античні часи зазначена форма творчості впроваджувала концепцію краси і величі вільної особистості, яка лейттемою проходить через праці Сократа, Платона, Аристотеля та н. В середні віки цей жанр реалізовував пошуки відповіді на питання релігійно-морального гатунку, де центром поставала проблематика співвідношення людини і Бога (Августин Блаженний, Тома Аквінський та ін.). В епоху Відродження ідеї гуманізму та антропоцентризму знаходять своє здійснення у прекрасних портретах великої плеяди художників, які часто були провідними мислителями свого часу (Сандро Ботічеллі, Леонардо да Вінчі, Мікеланжело Буанаротті, Рафаель Санті, Тіціан та ін.). Ідеологія нового часу по-особливому тлумачить персону, виділяючи в ній то раціональний початок (Р. Декарт, Г. Лейбніц, Б. Спіноза та ін.), то ідеальну духовну складову частину (Г. Гегель, Ф. Фейєрбах, Ф. Шеллінг та ін.). Різноманітні філософські течії вплинули на розуміння змісту особистості, що отримало довершення в портреті. Як наслідок - трансформація жанру в первинних для нього видах мистецтва (живопис, скульптура) та, починаючи з XVII століття, поширення його в інших видах художньої діяльності (музика, література). В XX столітті портрет поступово проникає у психологію, соціологію, лінгвістику, право та ін.

Епоха модернізму характеризується ускладненням розвитку культури, антропологічною кризою. Результат - активізація наукових пошуків, які прагнуть знайти відповіді на вічні проблеми існування homo sapiens (М. Бахтіна, Е. Гуссерль, Ж.П. Сартр, К. Юнг та ін.). Вони безпосередньо чи опосередковано торкаються проблематики портрету у вимірі відображення внутрішнього світу особистості. Окреслимо кілька фундаментальних постулатів, що дають ключ до розуміння зазначеної у публікації квестії.

Німецький філософ, засновник феноменології й методу аналізу свідомості Е. Гуссерль, вперше звернув увагу на необхідність опанування психологічних аспектів жанру. Мислитель вказував на багатоаспектність семантичних шарів портрета, де його неоднозначність виступає антитезою самого художника. Він вважав, що буття психічного не може бути виміряним і описаним. І лише за допомогою інтуїтивно-емоційного осягнення натури, яке здійснюється через зображення, митець знаходить вихід до індивідуального, 
внутрішнього світу людини, до того, що не має яскравого вираження у фізичному вимірі єства ${ }^{1}$.

Грунтовними для усвідомлення змісту досліджуваного нами феномена стали погляди Жан-Поля Сартра. Він стверджував, що портретування $є$ прикладом інтенціональної природи свідомості й безпосередньо стосується мистецтвознавства. Такий підхід сприяв розумінню жанру з позиції трьох онтологічних пластів. Перший психологічний, відображає не лише зовнішні ознаки натури, але, що найважливіше, усвідомлює іiі внутрішній світ, осягає результати довершення основних життєвих напрямів. Другий - культурологічний, демонструє наслідок реалізації образу героя портрета в цивілізаційному вимірі. Третій - філософський, розглядає жанр у широкому ідеологічному контексті, об'єднує в єдину світоглядну картину весь спектр окремих фактів як про зазначений вид творчості, так і про людину. В такій інтерпретації особистість стає не тільки суб'єктом культури, але і об'єктом наукового пізнання.

Відомий дослідник Б.Р. Віппер у своїй праці «Проблема схожості в портреті» акцентує на конфлікті, що виникає між замовником зображення i майстром, який його виконує. Донатор прагне реалістичного втілення, а митець намагається реалізувати своє бачення персонажа, розкрити приховані психологічні змісти. Аналізуючи типові характеристики зазначеного жанру в різні історичні періоди, мислитель доходить висновку: найважливішою ознакою портрета $є$ його схожість із натурою. Однак відкритим залишається питання, наскільки глядач може прочитати і розшифрувати образ людини, який зображений на картині ${ }^{2}$.

Мистецтвознавець Яків Тугендхольд у роботі «Про портрет» доводить постулат, що у досліджуваному нами жанрі прослідковуються міцні зв'язки з психологією та соціологією.

Разом із тим особистість наділена неповторною індивідуальністю, тільки їй притаманним темпераментом, що є визначальним у побудові ii концепції життєтворчості. Вчений вказує на самодостатність портрета, завдяки чому зображує персону повніше, ніж вона проявляється в реальному бутті. Науковець розділяє естетичний та історичний типи подібності, також зазначає, що в культурі образ людини інтерпретований як результат реалізації їі індивідуальності ${ }^{3}$.

\footnotetext{
1 Современная западная философия: Словарь. 2-е изд. / сост.: В. Малахов, В. Филатов. Москва : Політиздат, 1991. С. 113.

${ }^{2}$ Виппер Б. Проблема сходства в портрете. Статьи об искусстве. Москва, 1970. C. $342-351$.

3 Тугенгольд Я.О портрете. Из истории западноевропейского, русского и соверского искусства. Москва, 1987. С. 68-87.
} 
Вивчення сутності портрету також представлено в багатьох гуманітарних дослідженнях. У культурологічному аспекті він розуміється як феномен цивілізації (С. Аверинцев, М. Бахтін, С. Іконникова, М. Каган, Ю. Лотман, Б. Марков, Т. Холостова). Це опис індивіда засобами різних видів творчості, де зображуваний об'єкт може бути частиною загального художнього опусу. У зазначеному жанрі проголошується цінність неповторності персони, утверджується думка, що ідеальне не протиставляється суб'єктивному, навпаки - реалізується через нього i y ньому. Отже, портрет стає особливою формою людинознавства, в якій отримують своє вираження соціальні, естетичні, етичні, філософські уявлення про особистість в історії культури.

В останні десятиліття мистецтвознавство розширює свою методологічну базу, використовуючи підходи з різних гуманітарних наук. Дедалі частіше ми спостерігаємо вживання такого поняття, як «психологічний портрет». Воно есплікується як комплексна ментальна характеристика homo sapiens, що містить опис iï внутрішнього устрою i можливості діяти у певних важливих обставинах. У процесі створення цього виду зображення необхідно враховувати характер, темперамент, мотивацію, здібності, емоційність, інтелектуальність, вміння спілкуватись, вольові якості, рівень самоконтролю, самооцінку.

$\mathrm{У}$ другій половині XX століття стали застосовувати дефініцію «соціальний портрет». Найчастіше вона використовується для виявлення домінуючих властивостей групи індивідуумів, об'єднаних за певними ознаками (професією, віком, гендером, віросповіданням, країною тощо). Ї̈̈ зміст розуміється як сукупність узагальнених параметрів конкретної громади, які проявляються під час комунікації й взаємодії. Портрет має за ціль змалювати зовнішній вигляд особистості (як представника об'єднання), а також дати ii психологічну ознаку. Індивід $є$ складником соціуму, він може реалізувати свій потенціал у суспільстві (внаслідок його прийняття, критики, байдужості та ін.). Через соціальний портрет ми маємо змогу віднайти те неповторне, оригінальне, що виділяє персону із загального натовпу.

Сучасна наукова думка апелює поняттями «інтелектуальний», «науковий», «філософський» портрет. Ці терміни ще не отримали свого грунтовного вивчення, досить часто вони сприймаються як синоніми. Однак вважаємо, що, зокрема, інтелектуальний портрет варто експлікувати як: комплекс різноманітних (раціональних, емоційних, художніх та ін.) способів осягнення індивідуума, що сприяють усвідомленню рівня його пізнавальної сфери (оригінальність та гнучкість мислення, продуктивність, здібність до аналізу і синтезу, інтенсивність уваги, пам'ять та ін.); специфіку особистісного розвитку 
(захопленість певними ідеями, лідерство, соціальна автономність, широта поглядів, гумор та ін.).

У вимірі розуміння портрета в образотворчому мистецтві цінними $\epsilon$ наукові праці М. Алпатова, Л. Жінкіна, В. Лазарева, Н. Тарабукіна та ін. Кожен науковець пропонує своє авторське бачення зазначеного виду творчості. Узагальнивши їх погляди, ми констатуємо, що це самостійний жанр, метою якого $\epsilon$ відображення візуальних характеристик моделі. Проте, втілюючи своє першочергове завдання передачу зовнішнього вигляду персони - портрет виходить на новий рівень, втілюючи духовне буття всього того, що $є$ внутрішнім єством особистості. Він, з одного боку, повторює в пластичних формах, лініях і фарбах живе обличчя, 3 іншого - здійснює його ідейно-художню інтерпретацію. Через втілення очевидної (доступної глядачу при первинному сприйняті) форми образу homo sapiens розкривається інтимне персонажу, відбувається діалог між глибинами людської душі й реально існуючим світом.

У XX столітті вчені починають осягати сутність музичного портрета. Нині вже з'явилася досить значна кількість наукових досліджень, які в різних аспектах опановують цю проблематику (B. Брянцева, I. Вежгевець, Л. Казанцева, В. Медушевський, В. Назайкінський, Лі Юньцзе та ін. ). Перші спроби написання інструментальних портретів датовані XVII-XVIII ст., однак своєї кульмінації він досяг у першій половині XIX ст. 3 того часу активно представлений у творчості європейських композиторів.

Музичний портрет відтворює образ людини, вона $\epsilon$ центром художнього твору. Специфіка цього зображення полягає в тому, що через мелодію, гармонію, фактуру, ритм тощо митець розкриває глибинні світоглядно-філософські, психологічні процеси буття персони, іiї емоції, особливості характеру, висвітлює зовнішні риси, своєрідність соціальної поведінки.

Аналіз змісту портрета у різних сферах наукового знання, художньої творчості дає нам розуміння того, що це діалогічний жанр, де віддзеркалюється сутність самого персонажа і митця, який його втілює. У цьому контексті використання надбань побудови портретів у різних видах мистецтва може сприяти вирішенню цього завдання.

\section{2. Творчий портрет як спосіб інтерпретації культури}

Вивчення значної кількості публікацій, присвячених розгляду функціонування певного митця, яскраво засвідчує, що часто, подаючи біографію креативної персони, осягаючи специфіку індивідуального авторського стилю, означаючи внесок у розвиток цивілізації, вчені вживають визначення «творчий портрет». Хоча сутність зазначеної 
дефініції, розгляд ऑii структурних компонентів, вираження відмінностей та спорідненості з життєписом у наукових працях ми не виявили. Маючи педагогічний досвід репрезентації творчого портрету діячів культури (лекторська практика у ВНЗ), пропонуємо власне бачення цього поняття, яке може стати алгоритмом написання нових зразків у цьому жанрі.

Як було зазначено вище, портрет зародився в образотворчому мистецтві й скульптурі. У цих видах художньої діяльності втілення персонажа відбувається в якийсь один момент його буття; обличчя особистості відображає багатство духовного сенсу, іiі історію, соціальний статус і т.д. Однак специфіка побутування цього різновиду творчості не передбачає реалізацію трансформації натури. За «кадром» залишається безліч аспектів існування героя. Глядач не може прогнозувати кінець його літопису, тому кожного разу це опус із відкритим фіналом.

Літературний портрет з'явився значно пізніше, ніж живописний i скульптурний (у XVIII-XIX ст.). Його особливості розкрито в роботах М. Андронікова, В. Барахова, Д. Ліхачова, О. Творогова. Усталеним визначенням цього жанру є нарис про біографію і творчість майстра, що подається як опис життєвого шляху, індивідуального стилю, суспільно-громадської позиції. Слід зауважити, що письменництво вербально передає сутність персонажа, а слово більш доступне для широкого загалу «споживачів» мистецтва, ніж художні образи, втілені музичними звуками, фарбами чи іншими засобами. 3 огляду на те, що література - це часовий вид творчості, то донесення змісту праці потребує відрізку хронотопу, що може сприяти глибшому проникненню у внутрішній світ героя. Разом із ним читач (слухач) переживає складні душевні колізії, проходить певні випробування, тим самим стає його другом-соратником, набуває мудрості у вирішенні онтологічних проблем. «Драматург», який «малює» образ, подає діяча в динаміці й еволюції. У такому параметрі людина вже не усвідомлюється нами як константа, їі думки і почуття змінюються під дією різних чинників.

Творчий портрет виник після своїх прототипів в інших видах мистецтва, тому став своєрідним синтезом найяскравіших проявів цього жанру. Він, як і літературний різновид, реалізовує постать майстра засобами слова, розгортає його зображення у просторі й часі, розкриває майже у всіх вимірах людського існування. Від живопису i скульптури творчий портрет увібрав вміння концентруватися на конкретному етапі буття й мистецькому зразку, що був створений героєм у певний життєвий період. Віддзеркалення персони здійснюється в аспекті їі здобутків. Акцент виставляється на 
матеріальних i духовних досягненнях особистості, характеристиці авторської манери. Разом із тим він має і психологічну, соціальну, культурологічну і філософську складові частини. Оскільки творчий портрет прагне зрозуміти і пояснити напруженість внутрішнього буття митця, під час його написанні автор мусить користуватися методологічними напрацюваннями психології. Така галузь гуманітаристики, як психологія творчості, намагається дати відповідь на складні питання народження креативу. Соціальний контекст, один із домінуючих у бутті будь-якої особистості, виставляє акцент у творчому портреті на зв'язок (чи боротьбу) його життя з соціальними процесами. Культурологія сприяє укоріненню образу митця як об’єкта творчого процесу в цивілізаційну систему, що сприяє усвідомленню місії майстра в житті людства. Філософія як універсальна наука збирає в цілісну онтологічну модель факти різних сфер існування митця.

Вищенаведені постулати дають нам змогу експлікувати поняття «творчий портрет» таким чином: мистецтвознавчий синкретичний жанр, який через вербальний опис майстра виявляє його зовнішню подобу, внутрішне єство, особливості громадського буття, аксіологічні та онтологічні параметри світогляду. Образ людини та художні твори інтерпретуються як відображення культурних ідеалів, суспільного кругозору сучасної суб'єкту епохи. Разом із тим портрет повідомляє нам про етичні й естетичні принципи, особливості філософського бачення дійсності «художника», який «зображає» постать креативної персони.

Ціллю діяльності митця часто виступає самопрезентація, вона $\epsilon$ осмисленим конструюванням власного існування. Ця тенденція не виключає продукування культурних артефактів, які одночасно постають певною демонстрацією життєвої моделі індивідуума. У цьому контексті звернення до творчого портрету сприяє розкриттю людської сутності не тільки «зображуваного» на ньому митця, але і самого автора опусу. Можемо припустити, що віддзеркалення особи стає опосередкованою автобіографією iï «живописця». Таким чином з'являється подвійне відтворення - екстравертного героя, якого портретують, та інтровертного - того, хто досліджує життя майстра (мистецтвознавця).

Зазначений жанр - синтез історичного й літературного, особистого й об'єктивного, реального і придуманого. Саме тому його провідною ознакою постає вміння функціонувати на межі багатьох гуманітарних наук (психології, соціології, філософії, культурології, філології, мистецтвознавства та ін.), вбирати їх методологічні засади.

Спорідненою творчому портрету є біографія, яка часто, навіть у наукових джерелах, розуміється як його синонім. Однак за значної схожості 3 досліджуваним нами жанром літопис митця має свою 
специфіку. Він фіксує оповідь про індивідуума від народження до смерті через висвітлення громадської, політичної і духовної ситуації. Смисловим ядром хронік митця є духовний світ, що інтерпретується через зовнішні обставини.

В. Лях та Н. Манжелевська вважають: «Біографічний опис акцентує увагу на вивченні життя людини в соціокультурному оточенні, де культура постає посередником у вивченні особливостей ії творчості, визначає індивідуальність, а також ступінь впливу повсякденної культури на формування реального життя» [6, с. 14]. Зазначений погляд демонструє залежність особистості від цивілізаційних чинників. Вони окреслюють своєрідність іï діяльності. Життєпис суб'єкта великою мірою зумовлений національними, історичними та іншими умовами, в яких він існує.

Тлумачення біографії з позиції креативності приводить нас до думки, що митець $є$ активним учасником історії. Вивчення його літопису допомагає розкрити складність й суперечність суспільного буття, надає певний досвід майбутнім поколінням у вирішенні антропологічних проблем, сприяє розумінню сучасності.

Біографія креативної персони значно ширша за хроніки пересічного громадянина. Вона $є$ особливим портретом епохи, ii світоглядною моделлю, соціальним концептом певної цивілізації. Творчий портрет особистісний вимір культури, в якому опуси конкретного майстра «малюють» його образ для всього людства.

Літопис завжди закінчується смертю. Творчий портрет, через реальні досягнення персонажа, які витримують найсерйозніше випробування - перевірку часом, виводить постать митця 3 кінечності буття. Художній зразок сприймається духовним артефактом, а життя його героя - це оповідь про реалізацію суб'єкта свого призначення, повне розкриття власного таланту, виконання вищої місії особистісного безсмертя.

Для того, щоб творчий портрет став способом пізнання індивідуальності, в його основу треба покласти біографію. Науковцю доцільно: ввести у цей жанр мемуари, спогади, щоденники, листування тощо; зрозуміти соціокультурну ситуацію та усвідомити історичні події, на тлі яких проходило існування майстра; осягнути національну, етнічну своєрідність креативної персони; вивчити факти приватного життя (особливо дитинства та специфіку відносин у сім'ї); виявити, в кого вчився, які естетичні засади сприйняв і розвинув. Треба бути дуже делікатним, зберегти право людини на особистісний простір. Досліднику належить дотримуватися етичних норм, але водночас не залишати поза увагою душевні колізії, бо вони зробили креативну 
персону справжньою: складною, напруженою, але 3 власним баченням себе, світу й своєї місії у ньому.

При написанні портрету акцент варто виставити на здобутках митця: розкрити основні періоди діяльності; зазначити, що вплинуло на стиль, чим зумовлене тяжіння до того чи іншого жанру, які новації майстер привносить у традиційні форми i методи; виявити співвідношення індивідуального із загальнолюдським, регіонального 3 цивілізаційним. Науковцю доречно здійснити культурологічний та мистецтвознавчий аналіз етапних опусів. Їх порівняння допоможе більш випукло побачити особистісну трансформацію та їі реалізацію у творчості. Важливо так «намалювати» портрет, щоб відкрити своєму герою шлях до безсмертя в історії й культурі.

\section{ВИСНОВКИ}

Отже, у результаті проведеного дослідження ми пропонуємо авторське визначення поняття «творчий портрет»: вербальне продукування комплексного образу персони шляхом відображення іiі зовнішніх ознак і внутрішніх інтенцій; висвітлення мистецького спадку, досягнень у духовній сфері; втілення соціального призначення й історичної місії; окреслення взаємозв'язків митця з суспільством i світом; демонстрація художнього пізнання індивідуума в особистісному вимірі; відтворення біографії через діяльність.

Особливістю творчого портрета є синкретичність, функціонування на порубіжжі різних галузей гуманітаристики (психології, соціології, філософії, філології, мистецтвознавства та ін.). Його написання вимагає від науковця: використання широкого спектра антропологічних знань; введення документальних матеріалів та художньої літератури з буття майстра та його доби; залучення культурологічних, мистецтвознавчих праць із проблеми аналізу та інтерпретації творчості; виявлення специфіки еволюції та зміни художнього методу; студіювання та реконструкції цілісності суб'єкта з метою виявлення цивілізаційної місії.

Творчий портрет передає сутність людини, головну життєву ідею, яка знаходить свою реалізацію у мистецьких зразках. Цнй жанр констатує існування особистості в культурі, втілює рефлексивний стан персони, сприяє розумінню індивідуального стилю героя та його епохи.

\section{АНОТАЦІЯ}

Мета статті - на основі аналізу та узагальнення праць із філології, мистецтвознавства та культурології сформулювати зміст поняття «творчий портрет», висвітлити його специфіку та основні критерії написання, виявити значення у пізнанні особистості митця. Методологія дослідження полягає в застосуванні аналітичного, 
культурно-контекстуального, компаративного, системно-структурного, аксіологічного методів для розкриття сутності творчого портрету як способу осягнення креативної персони. Наукова новизна - вперше в національному мистецтвознавстві подано визначення терміна «творчий портрет», виявлено його особливості, аргументовано думку, що вищезазначений феномен є засобом осягнення духовного світу майстра. Поняття «творчий портрет» ми інтерпретуємо як: вербальне продукування комплексного образу персони шляхом відображення їі зовнішніх ознак й внутрішніх інтенцій; висвітлення мистецького спадку, досягнень у духовній сфері; втілення соціального призначення й історичної місії; окреслення взаємозв'язків митця 3 суспільством і світом; демонстрація художнього пізнання індивідуума в особистісному вимірі; відтворення біографії через діяльність. Особливістю творчого портрета $є$ синкретичність, функціонування на порубіжжі різних галузей гуманітаристики (психології, соціології, філософії, філології, мистецтвознавства та ін.). Його написання вимагає від науковця: використання широкого спектра антропологічних знань; введення документальних матеріалів та художньої літератури з буття майстра та його доби; залучення культурологічних, мистецтвознавчих праць із проблеми аналізу та інтерпретації творчості; виявлення специфіки еволюції та зміни художнього методу; студіювання та реконструкції цілісності суб'єкта 3 метою виявлення цивілізаційної місії. Творчий портрет передає сутність людини, головну життєву ідею, яка знаходить свою реалізацію в мистецьких зразках. Цей жанр констатує існування особистості в культурі, втілює рефлексивний стан персони, сприяє розумінню індивідуального стилю героя та його епохи.

\section{SUMMARY}

The purpose of the article is shaping the meaning of the creative portrait, revealing its specifics and fundamental composition criteria, denoting its significance in an artist's personality cognition on the basis of the analysis and generalization of Philology, Art Research and Culturology theses. The research methodology presupposes implementing the analytical, culture and in-context, comparative, system and structural, axiological methods for revealing the essence of the notion as an artistic personality's cognition means. The scientific novelty of the research: for the first time in Ukrainian Art Research domain the definition of creative portrait was put forward; its specifics were singled out, argued that the phenomenon was justified to be a cognition mode of an artist's mental world.

Portrait in European art originated in painting and sculpture. Its characteristics are the transfer of external features of a person, the disclosure mental laws through the graphic image of a human. The portrait has 
undergone the development and transformation, gradually manifested in music, literature, cinema etc., received a scientific interpretation in Philosophy.

The term is actively used in Psychology, Sociology, Linguistics and Art Research. In modern culturological sources it is interpreted as: a way of aesthetic cognition of the individual (A. Alpatov, M. Andronnikov, L. Kazantsev, etc.); the highest kind of artistic practice (M. Andronnikova, L. Singer, A. Sidorov, etc.); a holistic description of the subject which expresses the leading features of the inner world (M. Andronnikova, L. Singer, W. Wipper, etc.). The presented views bring the understanding of the genre to the level of a certain form of anthropology.

In Ancient time portrait realized the concept of beauty and greatness of the free personality (Socrates, Plato, Aristotle and others). In the middle Ages it had been carried out searches on religious and moral issues where the problem of the relationship between human and God became a central (Blessed Augustine, Thomas Aquinas, etc.). In the Renaissance the idea of humanism and anthropocentrism was embodied in beautiful portraits of artists who were often the leading thinkers of their time (Sandro Botticelli, Leonardo da Vinci, Michelangelo Buanarotti, Raphael Santi, Titian, etc.). The worldview of modern time interprets human in different ways, highlighting either the rational beginning (R. Descartes, G. Leibniz, B. Spinoza, etc.) or the ideal spiritual component (G. Hegel, F. Feuerbach, F. Schelling, etc.).

The intensification of philosophical researches (M. Bakhtin, E. Husserl, J.P. Sartr, K. Jung, etc.) which look for answers the eternal problems of human existence comes as a result. They tried to reflect the inner world of a person. An amount of philosophers (E. Husserl, J.P. Sartre, B. R. Wipper) worked on the psychological, culturological, philosophycal aspects of the genre. The scientific works of M. Alpatov, L. Zhinkin, V. Lazarev, $\mathrm{N}$. Tarabukin and others are extremely valuable in the problem of understanding portraiture as an independent genre in the fine arts.

Since XX century scientists have begun to learn the essence of the musical portrait (V. Bryantseva, I. Vezhgevets, L. Kazantseva, V. Medushevsky, V. Nazaikinsky, Li Yunjie, etc.). The first attempts of instrumental "portraits" appeared in XVII and XVIII centuries but as a special form of depiction it culminated in the first half of the XIX century. The musical portrait recreates the image of a specific person, who has become the center of masterpiece. Its specificity is that through melody, harmony, texture, rhythm, etc. the artist reveals the deep philosophical, psychological processes of human life, his feelings, emotions, character traits, highlights the external features and specifics of social behavior. 
The literary portrait appeared much later than the pictorial and sculptural ones (in XVIII-XIX centuries) and it was revealed in the works of M. Andronikov, V. Barakhov, D. Likhachev, O. Tvorogov. It is an essay on biography and creativity of the master which presented as a description of life, individual style and social position, requires a certain segment of time for deeper understanding of hero's inner world. Together with him the reader (listener) experiences emotional collisions and becomes his colleague, acquires wisdom in solving difficult ontological problems. The "dramatist" who "paints" the image presents the figure in dynamics and evolution. A person is no longer perceived as a constant, his thoughts and feelings can be changed under the influence of various factors.

Creative portrait emerged after its prototypes in other arts, so it became a kind of synthesis of the brightest manifestations of this genre. As well as a literary one it realizes the master by means of words unfolds his image in space or time and reveals almost all dimensions of human existence. The creative portrait absorbed the ability to concentrate on a specific stage of being, creating the hero in a certain period of life. The emphasis is placed on material, spiritual achievements, characteristics of the author's manner. It also has psychological (answers the difficult questions of the birth of creativity), social (emphasizes the connection/struggle of his life with social processes), cultural (promotes the rooting of the artist's image as an object of a creative process in the system of civilization, contributes awareness of the master's mission in life) and philosophical (gathers into a holistic ontological model disparate facts of different spheres of the artist's existence) components.

So the concept of "creative portrait" can be explained as: syncretic genre of art which through the verbal description of the master reveals his appearance, inner nature, features of social life, axiological and ontological worldview parameters. The image of a person and works of art are interpreted as a reflection of cultural ideals, social outlook of the modern subject of the era, informs about ethical and aesthetic principles, features of philosophical vision of the "artist's" reality that "depicts" the figure of a creative person. The genre is a synthesis of historical and literary, personal and objective, real and invented.

In order for a creative portrait become a way of cognition of the individual it has been based on a biography. It is expedient for a scientist to: introduce memoirs, diaries, correspondence, etc.; recognize social and cultural situation; understand historical events; to comprehend national, ethnic originality of the creative person; to study facts of private life; to find out specific of his education, what aesthetic principles he perceived and developed. When writing a portrait emphasis should be placed on achievements of the artist: the main periods of activity; specifics of the style, 
the reasons for attraction to a particular genre, innovations in traditional forms and methods; the relationship between individual and universal etc.

So the creative portrait is: a verbal conformation of a personality's complex image via reflecting its external characteristics and inner intentions; a manifesting of artistic heritage and achievements within cultural domain; an embodiment of social purpose and historical mission; shaping an artistcommunity-world interaction; a demonstrating of an individual's artistic cognition within intrapersonal domain; biography reproduction via activity. The creative portrait's specific feature presupposes its syncretic character and functioning within the borders of various humanitarian fields (Psychology, Sociology, Philosophy, Philology, Art Research, etc.). It requires: implementing wide spectrum of anthropological skills and awareness; introducing documentary information and fiction referring to artist's contemporaneity and epoch; involving research theses on Culturology and Art Research issues on the problem of analysis and interpretation of creativity; revealing specifics of the artistic method's evolution and transformations; a study and reconstruction of the individual's coherence with the goal of distinguishing civilizational mission. The genre manifests person's existence within cultural domain embodies his reflective state and contributes to comprehending a hero's unique style as well as his epoch's.

\section{ЛІТЕРАТУРА}

1. Виппер Б. Проблема сходства в портрете. Статьи об искусстве. Москва, 1970. С. 342-351.

2. Воронова М.Ю. Портрет і біографія. Гранична сутність жанрів : електронна бібліотека інституту журналістики. URL: http://journlib.univ.kiev.ua/index.php?act=article\&article $=1350$

3. Голубінка Н.I. Жанр літературного портрета в критиці Миколи Євшана. Поліграфія і видавнича справа. 2002. № 39. С. 149-154. URL: http://pvs.uad.lviv.ua/static/media/39/27.pdf.

4. Ли Юньцзе. Музыкальный портрет в контексте становления портретного жанра в изобразительном искусстве и литературе : автореф. дис. ... канд. искусствовед. : 17.00.09. Минск, 2013. 26 с.

5. Лотман Ю.М. Портрет. Статьи по семиотике культуры и искусства. Санкт-Петербург : Академический проект, 2002. С. 349-375.

6. Лях В.И., Манжелевская Н.И. Биографический метод в культурологическом исследовании. Культурная жизнь Юга России. 2016. № 3 (62). C. 14-16.

7. Микуланинець Л.М. Біографія митця як засіб інтерпретації культури. Українська культура : минуле, сучасне, шляхи розвитку. 2015. Вип. 21. Т. 2. С. 80-84. 
8. Невская П.В. Портрет в пространстве семиотики: вербальное и невербальное : автореф. дис. ... докт. искусствовед. : 17.00.09. Саратов, 2013. 49 c.

9. Сидорова Л.А. Публицистический вариант речевого жанра «портрет человека» : автореф. дис. ...канд. филол. наук : 10.02.01. Барнаул, 2005. 24 c.

10. Современная западная философия: Словарь. 2-е изд. / сост.: В. Малахов, В. Филатов. Москва : Політиздат, 1991. 544. С. 113.

11. Тугендхольд Я. О портрете. Из истории западноевропейского, русского и советского искусства. Москва, 1987. С. 68-87.

\section{Information about the authors:} Astalosh G. L.,

Candidate of Art History, Senior Lecturer at the Department of Chamber Ensemble and Quartet Lviv National Music Academy named after Mykola Lysenko 5, Nyzhankivskoho str., Lviv, Ukraine

Mykulanynets L. M.,

Candidate of Art History, Associate Professor, Associate Professor at the Department of Singing, Conducting and Music Theoretical Disciplines Mukachevo State University 59, Ya. Komenskoho str., Mukachevo, Ukraine 